\title{
Erratum to: Bacterial chitin utilization at halophilic conditions
}

\author{
D. Y. Sorokin · T. V. Kolganova
}

Published online: 30 January 2014

(C) Springer Japan 2014

\section{Erratum to: Extremophiles}

\section{DOI 10.1007/s00792-013-0611-z}

In the original publication of this paper the DSM number of strain HCh-An1 was incorrectly given as DSM26639. The correct number is DSM26670.

The online version of the original article can be found under doi:10.1007/s00792-013-0611-z.

D. Y. Sorokin $(\bowtie)$

Winogradsky Institute of Microbiology, Russian Academy of Sciences, Prospect 60-let Octyabrya 7/2, 117312 Moscow,

Russia

e-mail: soroc@inmi.ru; d.sorokin@tudelft.nl

D. Y. Sorokin

Department of Biotechnology, Delft University of Technology,

Delft, The Netherlands

T. V. Kolganova

Centre 'Bioengineering', Russian Academy of Sciences,

Prospect 60-let Octyabrya, 7/1, 117312 Moscow, Russia 